\title{
PERSEPSI MAHASISWA TERHADAP ATMOSFER TEMPAT MAKAN YANG MENGGUGAH SELERA TERHADAP MAKANAN TRADISIONAL
}

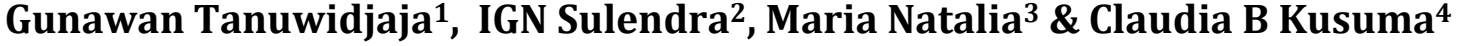 \\ ${ }^{1}$ Dosen(Fakultas Teknik Sipil dan Perencanaan, Prodi Arsitektur, UK Petra) \\ ${ }^{2}$ Dosen,(Fakultas Teknik Sipil dan Perencanaan, Prodi Arsitektur, UK Petra) \\ ${ }^{3}$ Mahasiswa (Fakultas Teknik Industri, Prodi Teknik Industri, UK Petra) \\ ${ }^{4}$ Mahasiswa (Fakultas Ekonomi, Prodi Manajemen Perhotelan, UK Petra) \\ *gunteitb2012@gmail.com
}

\begin{abstract}
ABSTRAK
Makanan tradisional merupakan sesuatu yang penting untuk karena dikonsumsi beberapa generasi, sesuai dengan selera masyarakat lokal dan dari bahan-bahan makanan lokal. Di sisi lain, makanan tradisional saat ini dipandang kurang menarik dibandingkan dengan makanan - makanan modern seperi fast food, maupun juga makanan asing seperti makanan Eropa, makanan Jepang dll. Karena itu, sangat diperlukan sebuah riset tentang persepsi mahasiswa terhadap atmosfer (suasana) tempat makan tradisional. Penelitian ini merupakan penelitian eksploratif mengenai dengan metode dokumentasi Visual Research oleh Sanoff (1991). Kemudian divalidasi dengan penyebaran kuesioner kepada para mahasiswa sesuai dengan parameter dari Kotler, (1973), Turley \& Milliman, (2000) serta Ariffin, dkk. (2011). Evaluasi kualitatif terhadap enam belas (16) restoran dan depot. Dan ditemukan tiga (3) tipologi yaitu: Restoran makanan tradisional yang bergaya arsitektur modern, Restoran makanan tradisional yang bergaya arsitektur tradisional, Depot makanan tradisional dengan atmosfer biasa. Dari ketiga perbandingan tipologi tempat makan yang menjual makanan tradisional di atas, didapati bahwa desain tempat makan yang menarik bagi mahasiswa UK Petra ialah restoran yang bergaya arsitektur modern, memiliki tingkat kebersihan yang baik, warna ruangan yang hangat dan pencahayaan yang hangat. Sehingga desain modern pada restoran ini dapat menjadi salah satu solusi untuk mempertahankan citra positif ini pada makanan bahkan budaya tradisional. Hal ini pada akhirnya akan melestarikan kebhinekaan ruang arsitektur nusantara.
\end{abstract}

Kata kunci: atmosfer, makanan tradisional, arsitektur modern, warna, pencahayaan

\section{Pendahuluan}

Makanan tradisional merupakan sesuatu yang penting. Hal ini dapat didefinisikan sebagai makanan umum yang biasa dikonsumsi sejak beberapa generasi, terdiri dari hidangan yang sesuai dengan selera manusia, tidak bertentangan dengan keyakinan agama masyarakat lokal, dan dibuat dari bahan-bahan makanan dan rempah-rempah yang tersedia lokal (Sastroamidjojo, S. 1995). Di sisi lain, makanan tradisional saat ini dipandang kurang menarik dibandingkan dengan makanan - makanan modern seperi fast food, maupun juga makanan asing seperti makanan Eropa, makanan Jepang dll.

Karena hal ini maka dipandang sebuah riset tentang persepsi mahasiswa terhadap atmosfer (suasana) tempat makan tradisional dilakukan sebuah penelitian multidisiplin berjudul: Persepsi Mahasiswa Universitas Kristen Petra Surabaya terhadap Makanan Tradisional. Penelitian ini dilakukan dengan bekerjasama para dosen dari Program Manajemen Pemasaran, Program Akuntansi Bisnis, Program Studi Arsitektur dan Program Studi Desain Komunikasi Visual. Karya tulis ini merupakan sebagian kecil 
temuan dari penelitian di atas. Pertanyaan penelitian yang dipaparkan dalam karya tulis ini ialah: Apakah kualitas atmosfer tempat jualan makanan tradisional yang mempengaruhi persepsi positif Mahasiswa Universitas Kristen Petra (UK Petra) terhadap makanan tradisional?

Mahasiswa UK Petra dipandang mayoritas berasal dari golongan ekonomi menengah dan atas sehingga pola konsumsi mereka cukup tinggi dan memiliki pilihan yang lebih luas terhadap berbagai jenis makanan di Surabaya. Sementara itu mereka akan menjadi pimpinan - pimpinan organisasi di masa depan (baik di sektor bisnis keluarga maupun perusahaan) sehingga persepsi positif mereka akan mempengaruhi juga pelestarian budaya tradisional, dalam hal ini makanan tradisional. Pelestarian ini selanjutnya akan mempertahankan kebhinekaan budaya dan juga ruang di Nusantara. Sehingga diharapkan selanjutnya kecintaan terhadap makanan tradisional dapat ditingkatkan dengan salah satunya menciptakan atmosfer tempat berjualan yang lebih menarik lagi.

\section{Tinjauan Pustaka}

Atmosfer sebuah tempat makan dapat didefinisikan secara bervariasi. Menurut Kotler, (1973) atmosfer ialah upaya untuk merancang membeli lingkungan untuk menghasilkan efek emosional tertentu dalam pembeli yang meningkatkan probabilitas pembeliannya. Hal ini dilakukan dengan sensasi penglihatan, suara, bau dan sentuhan. Sehingga faktor yang mempengaruhi ialah kombinasi visual (warna, pencahayaan, kedekatan dan jumlah elemen visual); aural (jenis musik, tingkat suara); taktil (kebersihan); dan penciuman (aroma). Sementara itu, atmosfer menurut Turley \& Milliman (2000) dapat didefinisikan sebagai komponen suasana interior yang dirasakan akan meliputi musik, suara, pencahayaan, aroma, warna, suhu, dan desain elemen visual.

Studi persepsi juga pernah dilakukan oleh Ariffin, dkk. (2011). Ariffin melakukan studi persepsi tentang atmosfer tempat makan atau restoran dengan penyebaran kuesioner dari responden terpilih dengan metode convenience sampling. Kuesioner tersebut mencakup tentang elemen suasana (atmosfer) restoran dan perilaku pelanggan. Dimensi untuk elemen atmosfer gaya restoran, tata letak restoran, warna restoran, pencahayaan restoran dan perabotan restoran. Dimensi untuk perilaku konsumen seperti dari mulut ke mulut, niat kembali datang, dan sikap terhadap restoran juga diadopsi. Dari total 300 responden yang terlibat, terdapat 108 laki-laki (36 persen) dan 192 perempuan (64 persen). Mayoritas responden berada di antara usia 21 dan 25 tahun (71 persen). Tingkat pendidikan responden berkisar dari Diploma (24 persen) dan Masters (14 persen). Mayoritas responden (62 persen) memiliki gelar sarjana. Hal ini merupakan studi yang relevan bagi riset ini.

Dalam riset tersebut, Ariffin, dkk. (2011) menemukan beberapa unsur-unsur suasana (atmosfer) yang tepat untuk pelanggan muda. Unsur gaya arsitektur memberikan kontribusi bagi perilaku pelanggan dalam berbagai cara. Ditemukan juga bahwa unsur-unsur suasana perlu diperbaiki agar pelanggan ingin datang kembali. Hal ini berarti diperlukan kreativitas dalam upaya pencahayaan, gaya restoran, selain itu juga perlu promosi dan iklan, kesaksian pelanggan.

Di sisi lain, warna interior bangunan memberikan dampak terhadap aspek pemasaran restoran menurut Singh, (2006). Menurut Singh warna dinding atau karpet akan meningkatkan penjualan makanan. Merah dan kuning menarik perhatian dan merangsang nafsu makan sementara pelanggan tenang biru dan hijau dan mendorong kegiatan makan yang lebih santai. 
Astuti \& Hanan, (2011) juga menemukan kaitan antara preferensi restoran dan kualitas atmosfer restoran yang didesain yang baik (suasana dan pelayanan) yang terutama digunakan oleh pemuda - pemudi untuk bersosialisasi. Di sisi lain ternyata ada pengaruh kelas restoran terhadap preferensi restoran - restoran.

\section{Metodologi}

Penelitian ini merupakan penelitian eksploratif mengenai dengan metode dokumentasi Visual Research oleh Sanoff (1991). Dari hasil survey dan analisa visual secara kualitatif dilakukan penyebaran kuesioner kepada para mahasiswa sesuai dengan parameter dari Kotler, (1973), Turley \& Milliman, (2000) serta Ariffin, dkk. (2011). Sehingga parameter yang dipilih dalam hal ini ialah:

- Desain bangunan dan interior tempat makan

- Kebersihan tempat makan (ruangan, peralatan makan, makanan)

- Temperatur ruangan tempat makan

- Suara musik di tempat makan

- Warna ruangan tempat makan

- Pencahayaan ruangan tempat makan

Evaluasi kualitatif terhadap restoran dan depot dilakukan. Terdapat enam belas (16) restoran dan depot yang dievaluasi berdasarkan parameter - parameter di atas. Parameter lain terkait bisnis tidak dibahas walaupun juga dievaluasi. Dilakukan pemilahan tipologi desain atmosfer (interior) yang berdasarkan gaya arsitektur sbb:

a. Restoran makanan tradisional yang bergaya arsitektur modern (PVIR, MR, FRIR, BK, RMPO, RSMP),

b. Restoran makanan tradisional yang bergaya arsitektur tradisional (PKJ, IBC, DK, DR, DOK, HG),

c. Depot makanan tradisional dengan atmosfer biasa (RS, LMNM, PMM, SSWWJ).

Kemudian dari analisa itu, kuesioner online disebarkan berisi beberapa parameter di atas. Setiap mahasiswa responden wajib berkunjung dan menikmati makanan di tempat makan tersebut di atas sebelum mengisi kuesioner tersebut. Kuesioner ini agar lebih dapat menggambarkan kualitas atmosfer dibuat degnan menggunakan skala 1-5 yang dimodifikasi dari skala Lickert. Skala ini digambarkan dengan 1 sebagai kualitas atmosfter yang paling rendah dan 5 untuk kualitas atmosfer yang paling tinggi. Dan sejumlah delapan puluh sembilan (89) orang responden berhasil dijaring dalam penelitian ini.

Contoh pertanyaan yang diberikan di antaranya ialah:

a. Latar belakang responden

1. Asal program studi.

2. Usia responden.

3. Jenis Kelamin.

4. Kesukaan terhadap makanan tradisional.

5. Frekuensi responden mengkonsumsi masakan tradisional (masakan daerah Indonesia).

b. Parameter terkait pelayanan tempat makan (tidak dibahas dalam riset ini)

1. Nama alamat tempat makan (restoran/ depot) yang dikunjungi responden.

2. Apakah responden baru pertama kali makan di tempat makan ini.

3. Nama tiga makanan favorit (sering dipesan) di tempat ini.

4. Apakah responden memesan salah satu dari makanan favorit tersebut.

5. Rasa makanan di tempat ini (1 makanan sangat tidak enak - 5 makanannya sangat enak). 
6. Kecepatan penyajian makanan (1 sangat lama - 5 sangat cepat).

7. Harga makanan di tempat ini (1 sangat mahal - 5 sangat murah).

c. Parameter terkait atmosfer tempat makan

1. Desain bangunan dan interior tempat makan (1 bangunannya sangat tidak menarik - 5 bangunannya sangat menarik)

2. Kebersihan tempat makan [ruangan, peralatan makan, makanan] (1 sangat kotor - 5 sangat bersih).

3. Temperatur ruangan tempat makan (1 suhu ruangan sangat panas - 5 suhu ruangan sangat sejuk).

4. Suara musik di tempat makan (1 musik sangat mengganggu - 5 musik sangat menenangkan).

5. Warna ruangan tempat makan (1 warna ruangan sangat tidak menarik - 5 warna ruangan sangat menarik).

6. Pencahayaan ruangan tempat makan (1 pencahayaan ruang sangat tidak nyaman - 5 pencahayaan ruang sangat nyaman).

Hasil kuesioner bagian $\mathrm{C}$ dibahas lebih lanjut, karena pertanyaan riset tentang atmosfer tempat makan yang menjual makanan tradisional di Surabaya.

\section{Hasil Dan Diskusi}

Karena menyadari terdapat perbedaan tipologi dari beberapa tempat makan di atas, dilakukan pembagian tipologi atmosfer di atas maka, pembahasan juga akan dibagi menjadi tiga jenis atmosfer tempat makan yang menjual makanan tradisional di Surabaya seperti:

1. Restoran makanan tradisional yang bergaya arsitektur modern (PVIR, MR, FRIR, BK, RMPO, RSMP),

2. Restoran makanan tradisional yang bergaya arsitektur tradisional (PKJ, IBC, DK, DR, DOK, HG),

3. Depot makanan tradisional dengan atmosfer biasa (RS, LMNM, PMM, SSWWJ).

\subsection{Restoran Makanan Tradisional Yang Bergaya Arsitektur Modern}

Terdapat enam (6) restoran yang memiliki desain atmosfer dengan gaya arsitektur modern. Hasil analisa kuesioner menunjukkan bahwa semua restoran ini dipersepsikan menarik. Empat puluh dua (42) responden menyukai gaya arsitektur modern ini (skor 3.76 dari skala 5 untuk atmosfer atau desain bangunan dan interiornya). Sementara warna ruangan dianggap lebih menarik (skor 3.67/ 5). Pencahayaan ruangan yang juga cukup menarik (skor 3.40/5). Sementara kebersihan tempat makan dianggap sangat baik (skor 3.95/5). Terakhir, temperatur ruangan (skor 3.48/5) dan suara musik di keenam restoran (skor 3.33/5) tersebut cukup baik.

\section{Tabel 1. Penilaian Responden Terhadap Kualitas Atmosfer di Restoran yang bergaya Arsitektur Modern}

\begin{tabular}{|c|c|c|c|c|c|c|}
\hline $\begin{array}{c}\text { Rata - Rata } \\
\text { Skor tentang } \\
\text { Atmosfer }\end{array}$ & $\begin{array}{c}\text { Desain } \\
\text { bangunan dan } \\
\text { interior } \\
\text { tempat makan }\end{array}$ & $\begin{array}{c}\text { Kebersihan } \\
\text { tempat makan } \\
\text { (ruangan, } \\
\text { peralatan } \\
\text { makan, } \\
\text { makanan) }\end{array}$ & $\begin{array}{c}\text { Temperatur } \\
\text { ruangan } \\
\text { tempat makan }\end{array}$ & $\begin{array}{c}\text { Suara musik } \\
\text { di tempat } \\
\text { makan }\end{array}$ & $\begin{array}{c}\text { Warna } \\
\text { ruangan } \\
\text { tempat makan }\end{array}$ & $\begin{array}{c}\text { Pencahayaan } \\
\text { ruangan } \\
\text { tempat makan }\end{array}$ \\
\hline $\mathbf{3 . 6 0}$ & 3.76 & 3.95 & 3.48 & 3.33 & 3.67 & 3.40 \\
\hline
\end{tabular}


Analisa kuesioner ini ternyata sejalan dengan analisa kualitatif yang dilakukan peneliti. Restoran - restoran ini memiliki gaya arsitektur modern dengan paduan warna - warna ruangan yang hangat (coklat, merah, krem). Desain yang modern ini memberikan kesan yang menarik bagi para konsumen walaupun mereka menyajikan makanan tradisional. Suasana yang baru ditambah, makanan yang enak dan kebersihan tempat makan (ruangan, peralatan makan, makanan) yang baik menyebabkan restoran - restoran ini lebih disukai. Selain itu pencahayaan yang bernuansa hangat (warna kuning) juga menambah popularitas tempat - tempat ini. Sementara itu aspek temperatur ruangan yang nyaman, dan suara musik juga membuat kualitas tempat ini lebih menarik.

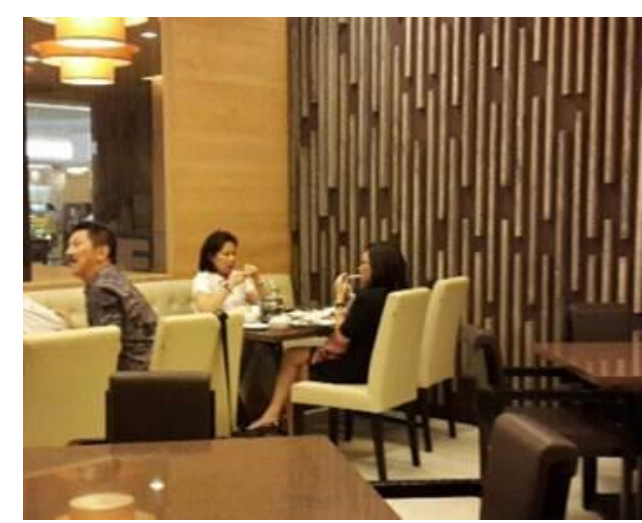

Gambar 1. Suasana Restoran PVIR

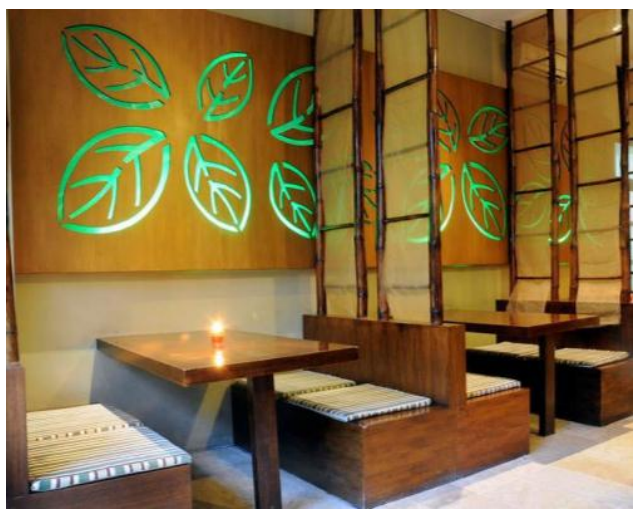

Gambar 3. Suasana Restoran MR

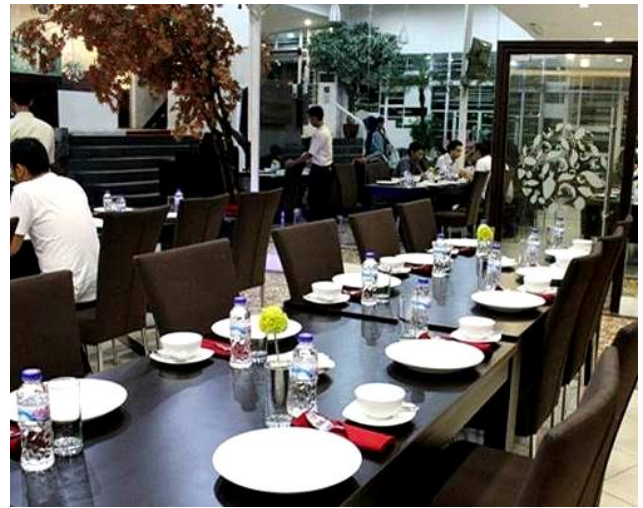

Gambar 2. Suasana Restoran RMPO

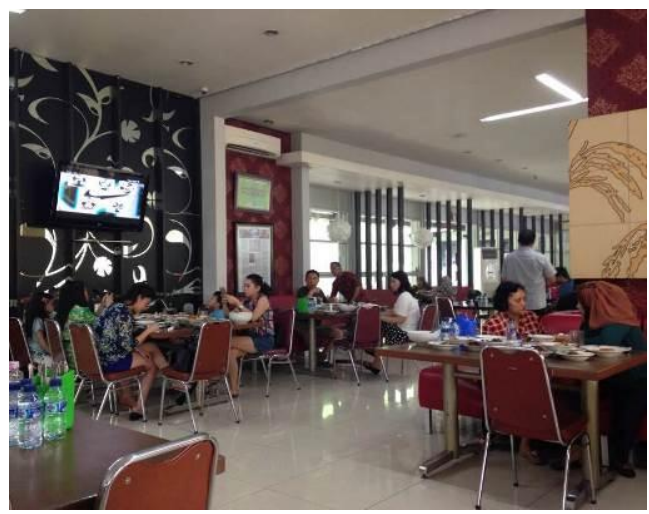

Gambar 4. Suasana Restoran RSMP

\subsection{Restoran Makanan Tradisional Yang Bergaya Arsitektur Tradisional}

Terdapat enam (6) restoran dengan atmosfer bergaya arsitektur tradisional. Dari hasil analisa kuesioner dapat disimpulkan bahwa, beberapa restoran ini dipersepsikan juga menarik. Karena 34 responden memberikan skor 3.71 dari skala 5 untuk desain bangunan dan interiornya. Walaupun demikian, lebih sedikit responden yang menyukai restoran - restoran dengan gaya tradisional. Sementara kebersihan tempat makan restoran - restoran ini dipandang sangat baik oleh responden (skor 3.88/ 5). Sementara temperatur ruangan juga sangat nyaman. Terakhir, suara musik (skor 3.62/ 5), warna ruangan (skor 3.44/5) dan pencahayaan ruangan (skor 3.38/5) dipersepsikan cukup menarik 
Tabel 2. Penilaian Responden Terhadap Kualitas Desain Arsitektur, Interior dan Grafis di Restoran yang Bergaya Arsitektur Tradisional Jawa atau Indonesia

\begin{tabular}{|c|c|c|c|c|c|c|}
\hline $\begin{array}{c}\text { Rata - Rata } \\
\text { Skor tentang } \\
\text { Atmosfer }\end{array}$ & $\begin{array}{c}\text { Desain } \\
\text { bangunan dan } \\
\text { interior } \\
\text { tempat makan }\end{array}$ & $\begin{array}{c}\text { Kebersihan } \\
\text { tempat makan } \\
\text { (ruangan, } \\
\text { peralatan } \\
\text { makan, } \\
\text { makanan) }\end{array}$ & $\begin{array}{c}\text { Temperatur } \\
\text { ruangan } \\
\text { tempat makan }\end{array}$ & $\begin{array}{c}\text { Suara musik } \\
\text { di tempat } \\
\text { makan }\end{array}$ & $\begin{array}{c}\text { Warna } \\
\text { ruangan } \\
\text { tempat makan }\end{array}$ & $\begin{array}{c}\text { Pencahayaan } \\
\text { ruangan } \\
\text { tempat makan }\end{array}$ \\
\hline $\mathbf{3 . 5 5}$ & 3.71 & 3.88 & 3.62 & 3.29 & 3.44 & 3.38 \\
\hline
\end{tabular}

Hasil analisa ini sejalan dengan analisa kualitatif peneliti. Gaya arsitektur tradisional Jawa atau Bali yang diadopsi yang didukung dengan warna dan material alam sangat menarik. Warna - warna hangat (coklat, krem, putih) dan material material alami (bambu, kayu, batu alam, beton yang tidak dirapikan atau non-finished) sangat sejalan dengan konsep tradisional yang sangat sesuai dengan sajian makanan tradisional Indonesia. Pencahayaan yang hangat (warna kuning) juga menarik pengunjung. Sayangnya seringkali, konsep arsitektur tradisional ini dipandang kurang menarik bagi pemuda - pemudi karena ketinggalan jaman.

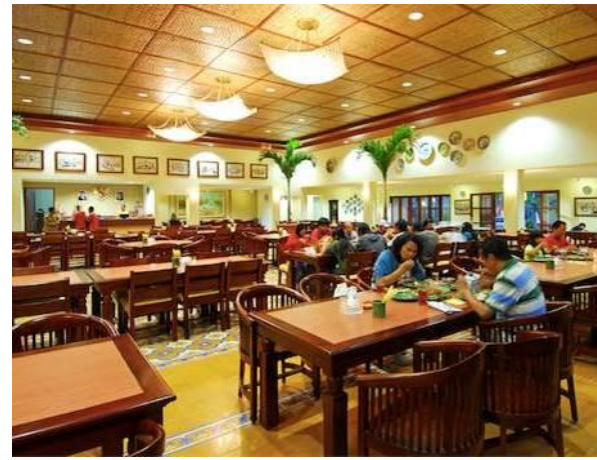

Gambar 5. Suasana Restoran IBC

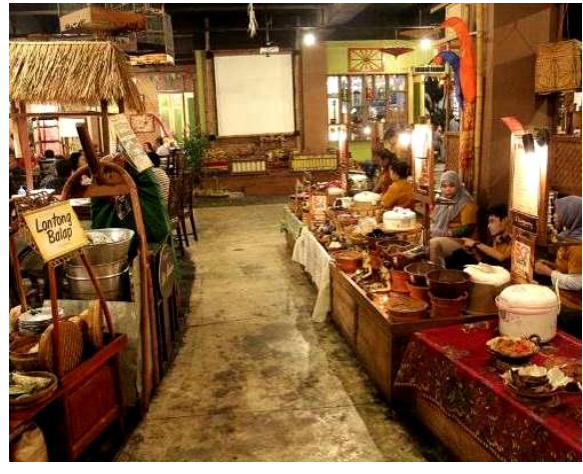

Gambar 6. Suasana Restoran DK

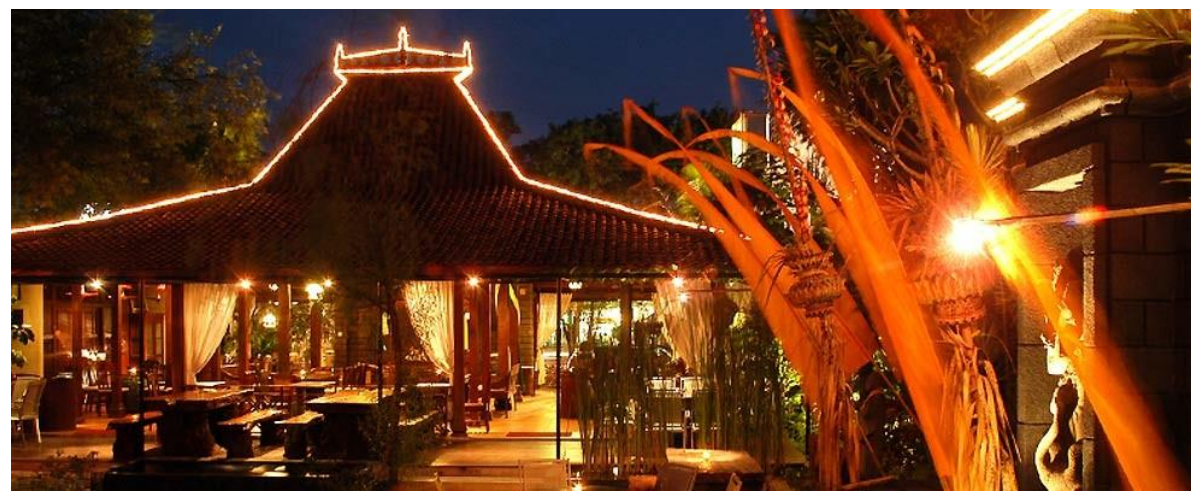

Gambar 7. Suasana Restoran DR

\subsection{Depot Makanan Tradisional Dengan Atmosfer Biasa}

Terdapat empat (4) depot makanan tradisional dengan atmosfer yang biasa saja. Tiga belas (13) responden merasa bahwa desain bangunan dan interior kelompok restoran ini biasa - biasa saja (skor 2.79 dari skala 5). Sementara kebersihan tempat makan (skor 3.23/5), temperatur ruangan (skor 2.92/5), suara musik (skor 2.31/5), 
warna ruangan (skor 2.85/ 5), dan pencahayaan ruangan (skor 2.77/ 5) juga dipersepsikan secara biasa - biasa oleh responden

\section{Tabel 3. Penilaian Responden Terhadap Kualitas Desain Arsitektur, Interior dan Grafis di Depot Biasa.}

\begin{tabular}{|c|c|c|c|c|c|c|}
\hline $\begin{array}{c}\text { Desain } \\
\text { Bangunan \& } \\
\text { Suasana }\end{array}$ & $\begin{array}{c}\text { Desain } \\
\text { bangunan dan } \\
\text { interior } \\
\text { tempat makan }\end{array}$ & $\begin{array}{c}\text { Kebersihan } \\
\text { tempat makan } \\
\text { (ruangan, } \\
\text { peralatan } \\
\text { makan, } \\
\text { makanan) }\end{array}$ & $\begin{array}{c}\text { Temperatur } \\
\text { ruangan } \\
\text { tempat makan }\end{array}$ & $\begin{array}{c}\text { Suara musik } \\
\text { di tempat } \\
\text { makan }\end{array}$ & $\begin{array}{c}\text { Warna } \\
\text { ruangan } \\
\text { tempat makan }\end{array}$ & $\begin{array}{c}\text { Pencahayaan } \\
\text { ruangan } \\
\text { tempat makan }\end{array}$ \\
\hline $\mathbf{2 . 7 9}$ & 2.69 & 3.23 & 2.92 & 2.31 & 2.85 & 2.77 \\
\hline
\end{tabular}

Hal ini sesuai dengan analisa kualitatif dari peneliti. Depot - depot ini memang dikenal oleh rasa makanan yang enak. Sehingga banyak konsumen datang ke depot depot ini untuk merasakan makanan tersebut. Tetapi karena keterbatasan permodalan serta sumber daya manusia, seringkali atmosfer tempat makan ini kurang mendapat sentuhan arsitektur secara profesional. Pemilihan warna - warna yang netral (putih, krem, merah muda) dan pencahayaan yang berkesan dingin (warna lampu putih) juga menurunkan kemenarikan tempat ini. Terakhir kebersihan tempat makan seringkali juga tidak diperhatikan dengan maksimal akibatnya persepsi konsumen tidak setinggi restoran - restoran yang lain.

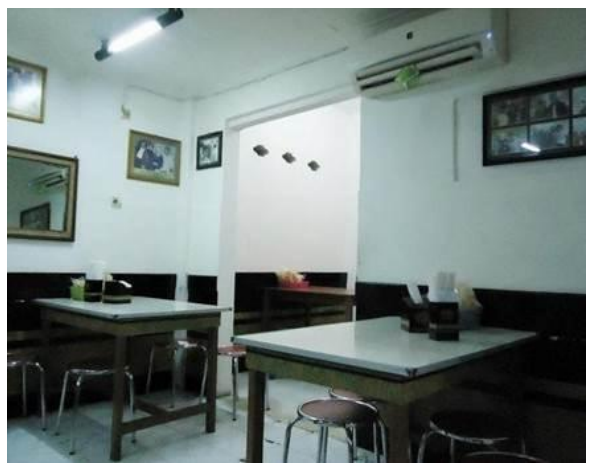

Gambar 8. Suasana Depot RS

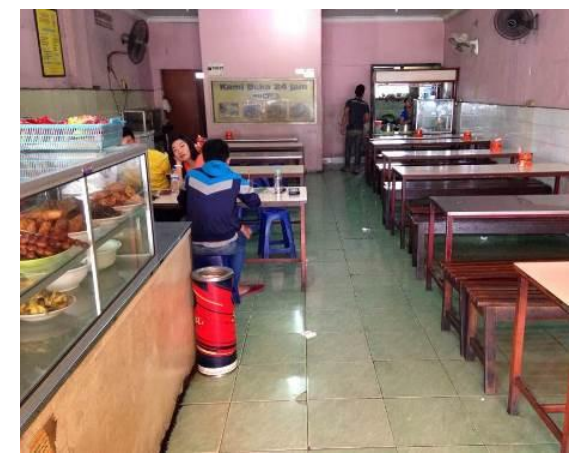

Gambar 9. Suasana Depot PMM

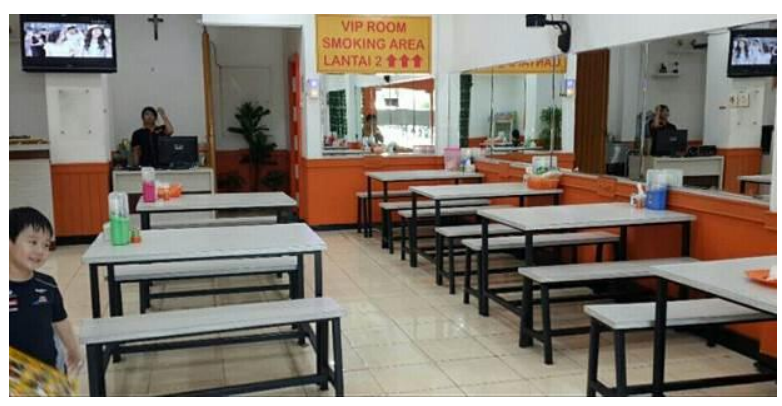

Gambar 10. Suasana Depot SSWWJ

Dari ketiga perbandingan tipologi tempat makan yang menjual makanan tradisional di atas, didapati bahwa restoran - restoran bergaya modern disukai oleh lebih banyak mahasiswa UK Petra. Kebanyakan responden tersebut memiliki persepsi bahwa restoran yang modern itu lebih bergengsi daripada restoran bergaya tradisional, maupun depot biasa-biasa. 
Di sisi lain, ternyata memang desain mempengaruhi citra positif konsumer terhadap tempat makan yang menjual makanan tradisional. Desain restoran dengan arsitektur modern maupun arsitektur tradisional dapat meningkatkan kesan positif pada budaya Indonesia terutama makanan tradisional Indonesia. Selanjutnya, desain tempat makan yang baik dengan pilihan warna - warna hangat dapat membuat restoran yang lebih menarik. Sementara itu, pencahayaan yang hangat (warna kuning) juga akan menciptakan suasana restoran yang lebih menarik. Hal ini pada akhirnya juga akan memberikan citra positif juga. Terakhir kebersihan tempat makan merupakan kata kunci keberhasilan atmosfer tempat makan yang menarik.

\section{Kesimpulan}

Desain tempat makan untuk makanan tradisional yang menarik bagi mahasiswa UK Petra ialah restoran yang bergaya arsitektur modern, memiliki tingkat kebersihan yang baik, warna ruangan yang hangat dan pencahayaan yang hangat. Hal ini sejalan dengan Ariffin, dkk. (2011) dan Singh, (2006). Tetapi kualitas rasa makanan, harga, dan kecepatan pelayanan juga harus diperhatikan. Desain modern pada restoran ini dapat menjadi salah satu solusi untuk mempertahankan citra positif ini pada makanan bahkan budaya tradisional. Hal ini pada akhirnya akan melestarikan kebhinekaan ruang arsitektur nusantara.

\section{Ucapan Terimakasih}

Kami mengucapkan terimakasih kepada:

- Dekan Fakultas Ekonomi, Liem Pei Fun SE., MComm.

- Ketua Program Manajemen Pemasaran: Drs. Sugiono Sugiharto, M.M.

- Para Rekan Peneliti: Ritzky K.M.R. Brahmana SE. MA., Priskila Adiasih SE. MSc. dan Heru Dwi W. MPd.

\section{Daftar Pustaka}

Ariffin, H.F., Bibon, M.F. \& Raja Abdullah, R.P.S. 2011. Restaurant's Atmospheric Elements: What The Customer Wants. Journal Of Asian Behavioural Studies, Volume 1, No. 2, May 2011.

Astuti, S., \& Hanan, H. 2011. The Behaviour Of Consumer Society In Consuming Food At Restaurants And Cafes. Journal Of Asian Behavioural Studies 1(1) January 2011 (Maiden Issue)

Kotler, P. 1973. Atmospherics As A Marketing Tool. Journal Of Retailing, 49(4), 48-64.

Sanoff, H. 1991. Visual Research Methods In Design. Department Of Architecture, School Of Design And Environment, North Carolina University, Van Nostrand Reinhold, New York.

Sastroamidjojo, S. 1995. Makanan Tradisional, Status Gizi, Dan Produktivitas Kerja. Dalam Prosiding Widyakarya Nasional Khasiat Makanan Tradisional. Jakarta: Kantor Menteri Negara Urusan Pangan. Hal 62-66.

Singh, S., 2006. Impact Of Color On Marketing. Management Decision, Vol. 44 No. 6, 2006, Pp. 783-789, Emerald Group Publishing Limited

Turley, L.W. \& Milliman, R.E. 2000. Atmospheric Effects On Shopping Behavior: A Review Of The Experimental Evidence. Journal Of Business Research, Vol. 49 No. 2, Pp. 193-211. New York: Harpercollins. 